\title{
Development of an Algorithm for Reducing Accidents in the External Power Supply System of Kuzbass Coal Mines
}

\author{
Roman Belyaevsky ${ }^{*}$, and Alexey Gerasimenko ${ }^{2}$ \\ ${ }^{1}$ T.F. Gorbachev Kuzbass State Technical University, 650000, 28 Vesennyaya St., Kemerovo, Russia \\ ${ }^{2}$ Siberian Federal University, 660041, 79 Svobodny Av., Krasnoyarsk, Russia
}

\begin{abstract}
One of the most important areas is to ensure the required reliability of power supply to coal mining enterprises. This problem is associated with the high hazard due to accidents at coal mines. The article discusses approaches to solving the problem of finding the best ways to improve the efficiency of the external power supply system. This makes it possible to increase the reliability of power supply to the coal mines of the Kemerovo region - Kuzbass. On the basis of the information method, an algorithm has been developed that makes it possible to take into account the topology of the electrical network, increasing its reliability. Measures to improve the external power supply of LLC "Mine" Pervomayskaya" are proposed and substantiated. A feasibility study for the direction of increasing the stability of the structure of the electrical network is presented.
\end{abstract}

\section{Introduction}

In modern conditions, the improvement of technological processes, the corresponding software and information tools and the associated continuous development of production require from the power supply systems of industrial enterprises to ensure the required level of reliability, quality of electricity and efficiency. At the same time, coal industry enterprises have their own special requirements for the reliability of power supply, determined by the specifics of mining.

Since the Kemerovo Region - Kuzbass is a large coal mining and industrial center, one of the priority tasks of power supply in the region today is still a reliable power supply to coal enterprises. Increased requirements for the reliability of power supply to these consumers are imposed in connection with safety conditions. This is due to the fact that the development of emergencies, including explosions, the formation of methane in places of work of people, fires, begins with a sudden cessation of power supply to individual technological processes, as well as the entire coal enterprise [1].

With full compliance with current regulations, the power supply of industrial electrical receivers of the I and II reliability categories, which include coal enterprises, is carried out

${ }^{*}$ Corresponding author: brv.egpp@kuzstu.ru 
from the redundant bus section of the distribution substation. It is powered by two power lines from the main power source. This source can be one or more main step-down substations for an industrial plant. Due to the location of the supply lines in close proximity to each other, the presence of two independent mutually redundant sources for electrical receivers does not always provide uninterrupted power supply. It also does not guarantee that the time of the forced power outage will not go beyond the permissible limits established by the current regulatory legal acts.

On the territory of Kuzbass, with the existing schemes of external power supply of coal enterprises, the requirements are practically not met in full. Thus, ensuring uninterrupted power supply is hampered by the imperfection of external power supply schemes. This can negatively affect the efficient functioning of the power supply systems of coal enterprises. Therefore, the study and search for approaches to improving the reliability of their power supply is an urgent task today.

\section{Study Objects and Methods}

To assess the situation in the field of reliability of power supply to the coal mines of the Kemerovo region - Kuzbass, it is necessary to analyze technological outages at mines, identify the causes of power outages and establish a hierarchical order of factors that served as prerequisites for technological disruptions in the electric networks of coal mines.

Below is an analysis of technological disturbances at the mines of Kuzbass for the period 2017-2020.

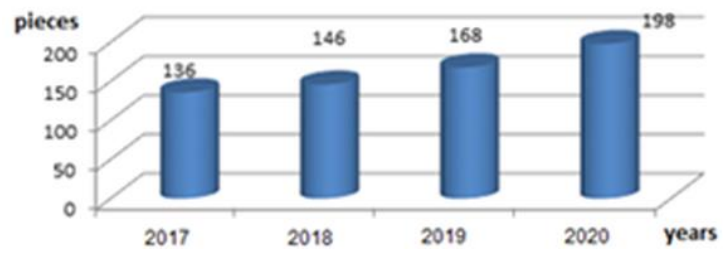

Fig. 1. The number of technological outages at the mines of the Kemerovo Region - Kuzbass.

Fig. 1 shows that the largest number of power outages was recorded in 2020. Moreover, the number of technological violations is increasing every year.

The main reasons for emergency shutdowns of coal mines in Kuzbass for the period 2017-2020 are shown in Fig. 2.

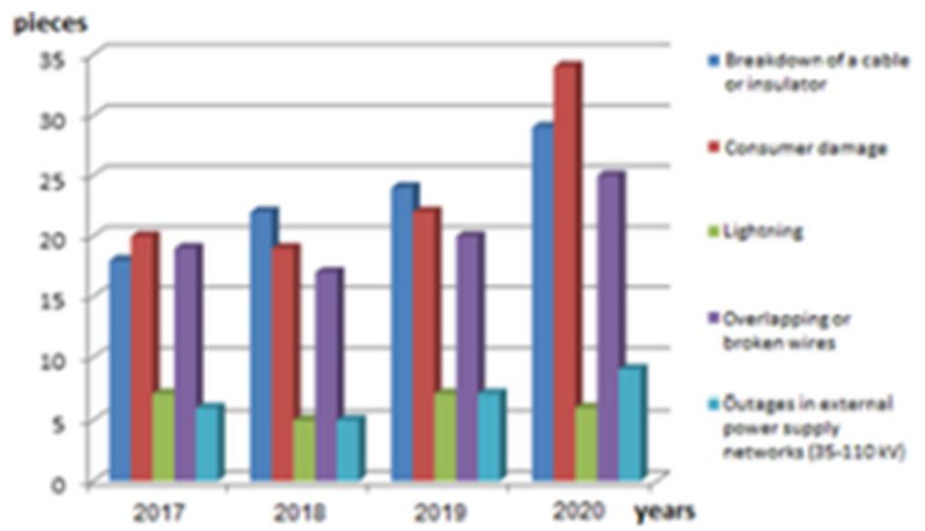

Fig. 2. The main reasons for technological outages in the mines of the Kemerovo Region - Kuzbass. 
Analyzing the histogram, we can conclude that the main cause of technological disturbances is damage at the consumer, that is, in the equipment of a coal mine, such as:

- short circuit in the electric motor;

- damage to the lead-in switch in the switchgear cubicle;

- damage to the technological equipment of the mine;

- damage on starting engines, drainage, pump, etc.

In addition, entanglement of wires and breakdown of a cable or insulator in the $6 \mathrm{kV}$ power grids of coal mines are significant causes of power outages. As for technological outages that occurred due to damage in the external power supply networks of $35-110 \mathrm{kV}$ mines, in 2020 their share of the total number of outages was $4.6 \%$. Due to thunderstorms, emergencies occurred in $3 \%$ of cases.

For an objective assessment of the damage to coal mines from technological disturbances, it is additionally necessary to analyze the average shutdown time (Fig. 3). It can be seen from the histogram that the average time of technological disruption in mines due to damage to equipment at a consumer does not exceed two hours. At the same time, due to an emergency breakdown in external electrical networks with a voltage of 35-110 $\mathrm{kV}$, the average downtime of mine equipment is more than three hours.

Thus, outages in external power grids cause significant damage to coal enterprises, disrupting the safe operation of equipment and putting significant danger to workers who are underground at the time of an emergency.

A large number of domestic and foreign works are devoted to the study of the issues of reliability of power supply [2-8]. However, they, as a rule, lack aspects that directly or indirectly affect the trouble-free operation of the power supply systems of coal enterprises.

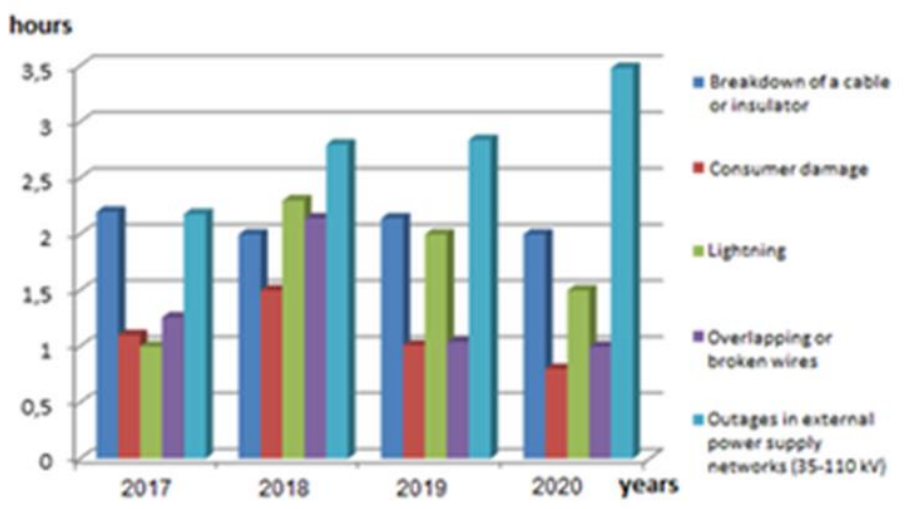

Fig. 3. Average duration of emergency outages due to the main causes of technological disturbances in coal mines.

For example, there is no assessment of the technical condition of the external power supply system of coal enterprises. The issue of technological connection for coal mining enterprises according to the category of power supply reliability required by the enterprise has not been touched upon. This aspect is important due to the fact that according to the Rules for Technological Connection of Power Receiving Devices of Consumers to Power Grids, coal enterprises independently choose the category of reliability. But this does not take into account that there are consumers in mines who belong not only to categories I and II, but also to a special group of power consumers in terms of the reliability of power supply. Also, the issue of the lack of established unambiguous criteria for assigning power consumers to a special group in terms of power supply reliability and methods for determining power receivers of technological and emergency power supply armor has not 
been worked out. There are no modern approaches to assessing the economic damage from interruptions in the power supply of mines. These aspects currently require additional study, the purpose of which is to improve the reliability of the power supply systems of coal enterprises.

Consider the existing calculation methods that are currently used to study the reliability of power supply systems. They make it possible to reduce accidents and injuries, both at the design stage and throughout the entire service life of the power supply systems of coal enterprises.

The analytical method for calculating reliability differs in that, based on the formulas for the reliability indicators of parallel and series connection schemes, it is possible to determine the frequency and duration of consumer shutdowns. This method is visual, it allows calculating the reliability indicators of circuits with relatively simple mathematical operations. At the same time, the method is characterized by a significant complexity of formalization, it has not been brought to machine algorithms and programs, and it allows one to analyze systems of only a simple structure. It lacks a unified mathematical model of the reliability of the systems functioning. There are difficulties in the study of nonstationary characteristics of reliability, it is impossible to study dependent processes, to analyze systems with variable structure [9].

The logical-probabilistic method for calculating the reliability can be used for any logical structure of the system (not only for serial-parallel logical circuits). It can be used for any distribution of MTBF. At the same time, it is difficult to compose a logical function of operability that quite accurately corresponds to the system under consideration. The existing methods of transition from logical to probabilistic models of system reliability are very laborious even with their computer implementation. Also, the method does not allow constructing non-monotonic models of system reliability, i.e., there is no ability to function in different states with different efficiency. The available methodological tools of the logical-probabilistic method have not yet been fully algorithmicized. This limits its practical application for operational analysis of the reliability of even monotonous, qualitatively simple systems [10].

The method for calculating the reliability of the electrical network for the shortage of electricity allows you to assess the probability of breakage of individual lines and connections. The method makes it possible to assess the material losses that would be caused to consumers in the event of a shortage of electricity. However, calculating the final probability of a state taking into account the cascade development of an accident is a very difficult task. This requires a lot of data processing. But to determine the mathematical expectation of undersupply of electricity, it is not enough, since it does not reflect the proper properties of the system to withstand disturbances, preventing their cascade development [11].

The information method for calculating the reliability of power supply allows you to evaluate the efficiency of the functioning of complex systems. In a structural study, the system is considered as an independent object, for which a model is built using a minimum set of initial data. The method makes it possible to take into account the ergatic system, identify profitable power transmission paths, and develop the most efficient operation and maintenance schemes. The disadvantage of the information method is the lack of a unified methodology for the construction of mathematical models [12].

Table 1 presents the characteristics of methods for calculating the reliability of power supply. They will allow you to determine the most optimal method for calculating reliability. The main ones include clarity, applicability for any logical structure, assessment of the functioning of complex systems, the availability of calculating indicators, practical application of the method, applicability at the design stage, assessment of material losses. 
Table 1 shows that the information method for calculating reliability has a significant advantage in terms of its characteristics in comparison with other considered methods. The main disadvantage of this method is the impossibility of assessing material losses. Otherwise, this method fully meets all the requirements for methods for calculating the reliability of power supply.

Table 1. Results of a comparative analysis of methods for calculating the reliability of power supply.

\begin{tabular}{|l|c|c|c|c|c|c|c|}
\hline Method & \multicolumn{6}{|c|}{ Criteria characteristics } \\
\cline { 2 - 8 } & $\begin{array}{c}\text { Visibili } \\
\text { ty }\end{array}$ & $\begin{array}{c}\text { Applicabi } \\
\text { lity for } \\
\text { any } \\
\text { logical } \\
\text { structure }\end{array}$ & $\begin{array}{c}\text { Assessm } \\
\text { ent of } \\
\text { the } \\
\text { functioni } \\
\text { ng of } \\
\text { complex } \\
\text { systems }\end{array}$ & $\begin{array}{c}\text { Availabil } \\
\text { ity of } \\
\text { calculati } \\
\text { ng } \\
\text { indicator } \\
\text { s }\end{array}$ & $\begin{array}{c}\text { Practica } \\
\text { l } \\
\text { applicati } \\
\text { on of the } \\
\text { method }\end{array}$ & $\begin{array}{c}\text { Applicabi } \\
\text { lity at the } \\
\text { design } \\
\text { stage }\end{array}$ & $\begin{array}{c}\text { Assessm } \\
\text { ent of } \\
\text { material } \\
\text { losses }\end{array}$ \\
\hline Analytical & + & - & - & - & + & + & - \\
\hline $\begin{array}{l}\text { Logical- } \\
\text { probabilist } \\
\text { ic }\end{array}$ & - & + & + & - & - & + & - \\
\hline $\begin{array}{l}\text { Calculatio } \\
\text { nof the } \\
\text { reliability } \\
\text { of the } \\
\text { electrical } \\
\text { network } \\
\text { for the } \\
\text { undersupp } \\
\text { ly of } \\
\text { electricity }\end{array}$ & - & - & - & + & - & - & + \\
\hline $\begin{array}{l}\text { Informatio } \\
\text { nal }\end{array}$ & + & + & + & + & + & + & \\
\hline
\end{tabular}

\section{Results and Discussion}

The introduction of an information method for calculating the reliability of power supply makes it possible to draw up an algorithm that is applicable to reduce the accident rate in the external power supply systems of coal mines (Fig. 4).

At the first stage, a directed graph is drawn up. The branches of the graph represent cable and overhead power lines. The orientation of the graph branches corresponds to the potential flows of electricity in the electrical network. Therefore, the constructed directed graph reflects the studied power supply system as much as possible.

At the second stage, it is necessary to analyze the structural indicators that make it possible to classify the power supply system according to the characteristic properties of the structure [13]. You should also apply recommendations for improving its structure, identify "key points" - substations (busbars), the operation of which should be given special attention.

At the third stage, the saturation of the investigated power supply system with operational information is determined. Bottlenecks are identified that slow down the flow of operational information. Recommendations are developed for the expedient increase in the saturation of the system with operational information.

The fourth stage makes it possible to assess the efficiency of the functioning of the power supply system and determine the need for its improvement. 
The fifth stage makes it possible to take into account the technical and economic indicators of the power supply system.

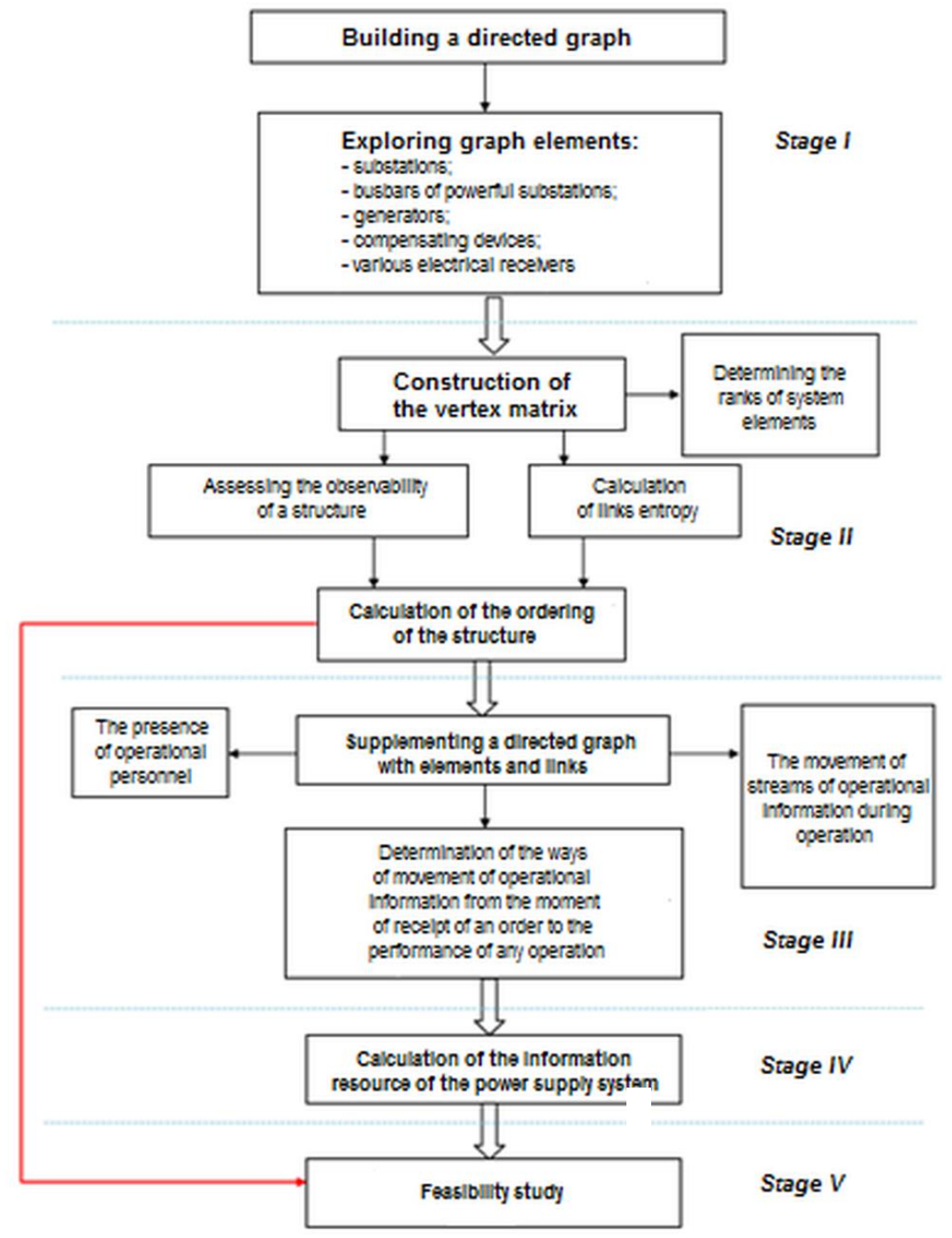

Fig. 4. Algorithm for reducing accidents in external power supply systems.

Let us consider the application of the developed algorithm in stages using the example of a hazardous production facility of the first hazard class - the LLC "Mine" Pervomayskaya". The enterprise is a structural subdivision of JSC "Coal Company "Severny Kuzbass" and belongs to consumers of the first category of power supply reliability.

At Pervomayskaya Mine, the first reliability category electrical receivers include: main ventilation fans, main drainage system, BKRU-6 switchgear, diesel generator set, degassing, cage lift, boiler room. External power supply to the mine is carried out акщь а $35 \mathrm{kV}$ double-circuit overhead line from the $220 \mathrm{kV}$ "Krokhalevskaya" substation.

Currently, the mine is coordinating a project for the reconstruction of a double-circuit overhead line into two single-circuit lines. However, this circumstance does not exclude the 
possibility of an emergency at the $220 \mathrm{kV}$ "Krokhalevskaya" substation with complete redemption of $35 \mathrm{kV}$ busbar sections. Thus, it is necessary to offer alternative options for external power supply to LLC "Mine" Pervomayskaya".

After analyzing the power supply scheme of the network section located in the northern part of the Kemerovo region - Kuzbass, we can conclude that it is possible to supply the Pervomayskaya mine with an additional source of electrical energy from the 110/35/6 kV "Anzherskaya NPS" substation. The distance from the $35 \mathrm{kV}$ "Pervomayskaya" substation to this substation is $50 \mathrm{~km}$.

The second option for additional power supply to the Pervomayskaya mine is the overhead line from the $35 \mathrm{kV}$ "Pervomayskaya" substation to the $35 \mathrm{kV}$ "Promyshlennovskaya" substation. The distance will be $27.2 \mathrm{~km}$ by making a jumper between the $35 \mathrm{kV}$ busbar sections and installing one switch on the side of the $35 \mathrm{kV}$ "Pervomayskaya" substation.

Another possible option for supplying an additional source of electrical energy is an overhead line from the $35 \mathrm{kV}$ "Pervomayskaya" substation to the $110 / 35 / 10 \mathrm{kV}$ "Rudnichnaya" substation. The length of the line will be $35.8 \mathrm{~km}$, making a jumper between the $35 \mathrm{kV}$ busbar sections and installing two switches on the side of the $35 \mathrm{kV}$ buses of the "Pervomayskaya" substation and the $35 \mathrm{kV}$ buses of the 110/35/10 kV "Rudnichnaya" substation.

However, the construction of an overhead line with a length of more than $40 \mathrm{~km}$ is impractical. As a result, the option of building an overhead line from the $110 / 35 / 6 \mathrm{kV}$ "Anzherskaya NPS" substation to the $35 \mathrm{kV}$ "Pervomayskaya" substation is not considered in the article. Choosing between the two remaining options, it is necessary to assess the reliability of the existing power supply scheme for the energy district of the Pervomayskaya mine. It is also necessary to analyze the reliability of the power supply system after the proposed measures for the construction of a third independent source of power supply for the coal mine.

At the second stage of applying the algorithm, it is necessary to present a diagram of the external power supply of the circuit section. It is also necessary to construct a directed graph according to this scheme, indicating the possible ways to increase the external power supply of the Pervomayskaya mine, proposed at the first design stage.

On the basis of a directed graph, it is necessary to construct a vertex adjacency matrix $\left(M_{i j}\right)$, which reflects the presence of connections between the vertices of the $i$-th element and other vertices of the circuit [14].

Next, you need to determine an estimate of the observability of the system:

$$
A=\frac{\operatorname{rank}\left(M_{G}\right)}{s_{m}},
$$

where $s_{m}$ - number of matrix elements, $M_{G}$ - adjacency matrix.

After that, the frequency of using links for the $i$-th element of the system is calculated:

$$
\lambda_{i}=\frac{p_{i}}{p_{\Sigma}}
$$

where $p_{i}-$ number of element links, $p_{\Sigma}-$ total number of links.

Calculations of two options for an additional power source for the Pervomayskaya mine are carried out similarly to the presented calculation of the original power supply system. The calculation results are summarized in Table 2. 
Table 2. Comparative analysis of power supply options for LLC "Mine "Pervomayskaya".

\begin{tabular}{|l|c|c|c|}
\hline \multicolumn{1}{|c|}{ Power supply option } & $\boldsymbol{A}$ & $\boldsymbol{H}(\boldsymbol{p})$ & $\boldsymbol{G}$ \\
\hline Original schema & 0,935 & 0,822 & 0,768 \\
\hline Option 1 & 0,935 & 0,832 & 0,778 \\
\hline Option 2 & 0,968 & 0,843 & 0,816 \\
\hline
\end{tabular}

From Table 2 it follows that the most optimal option is the considered second option of power supply, namely the construction of an overhead power supply from the $35 \mathrm{kV}$ "Pervomayskaya" substation to the 110/35/10 kV Rudnichnaya substation with a jumper between the $35 \mathrm{kV}$ bus sections and two switches on the bus side $35 \mathrm{kV}$ substation $35 \mathrm{kV}$ "Pervomayskaya" and $35 \mathrm{kV}$ busbars of the substation 110/35/10 kV "Rudnichnaya".

At the third stage of the algorithm application, it is necessary to analyze the receipt and transmission of operational information in the event of an emergency at LLC "Mine "Pervomayskaya". The power supply center at the present time for this mine is the $220 \mathrm{kV}$ "Krokhalevskaya" substation with permanent duty operational personnel at the control panel of this substation. The $35 \mathrm{kV}$ "Pervomayskaya" substation also has round-the-clock operational personnel. Then we can conclude that from the transmission of information to the receipt and execution of the dispatcher's commands, the time elapses is less than three minutes in an emergency. It should be borne in mind that the coal mine belongs to the first category of consumers. The permissible shutdown time is taken by the response time of automatic transfer switches, which also reduces the time between receiving information and executing commands.

In the case of improving the electrical circuit by a third independent overhead line connected to the $35 \mathrm{kV}$ buses of the $110 / 35 / 10 \mathrm{kV}$ "Rudnichnaya" substation and the $35 \mathrm{kV}$ buses of the "Pervomayskaya" substation, we will get the same transmission and reception system as with the existing circuit. This is due to the fact that operational personnel are on duty around the clock at the $110 / 35 / 10 \mathrm{kV}$ cRudnichnaya" substation.

If we apply the option with the third independent power supply from the $35 \mathrm{kV}$ buses of the "Promyshlennovskaya" substation to the $35 \mathrm{kV}$ buses of the "Pervomayskaya" substation, then the most rational way is to set the automatic switching on of the reserve line. This will allow, in the event of complete repayment of both $35 \mathrm{kV}$ overhead lines from the $220 \mathrm{kV}$ "Krokhalevskaya" substation to the $35 \mathrm{kV}$ "Pervomayskaya" substation, to automatically switch on a $35 \mathrm{kV}$ backup line from the buses of the $35 \mathrm{kV}$ "Promyshlennovskaya" substation to the buses of the $35 \mathrm{kV}$ "Pervomayskaya" substation. Thus, we exclude the time for switching the operational field team, minimizing the influence of the human factor, increasing the reliability of the entire system. Based on the above, we accept the transfer of operational information from the power source to the consumer equal to the response time of the automation, that is, no more than $0.02 \mathrm{~s}$.

It is important to calculate the information resource for a power supply system where there is no permanent operating personnel at the substation or the distance between the switching point and the base of operating personnel reaches several hundred meters. The article provides an analysis of the power supply system of a coal mine with operational personnel, the base of which is located where the main control panel is located. Thus, it is impractical to calculate the information resource of the power supply system.

Further, according to the algorithm, it is necessary to estimate the costs of building an overhead line and determine the terms of its recoupment.

Consider two options for the construction of overhead lines:

1. construction of an overhead line from the buses of the $35 \mathrm{kV}$ "Promyshlennovskaya" substation to the buses of the $35 \mathrm{kV}$ "Pervomayskaya" substation;

2. construction of an overhead line from the $35 \mathrm{kV}$ busbars of the 110/35/10 "Rudnichnaya" substation to the buses of the $35 \mathrm{kV}$ "Pervomayskaya" substation. 
Table 3 presents a comparative analysis of the costs of LLC "Mine "Pervomayskaya" for the construction of an overhead line for the two proposed options for improving the power supply system.

Table 3. Costs of LLC "Mine "Pervomayskaya" for the construction of an additional independent power source.

\begin{tabular}{|c|c|c|c|c|}
\hline № & Cost criteria & $\begin{array}{c}\text { Fee rate, } \\
\text { rubles / km / } \\
\text { Equipment } \\
\text { cost, rubles }\end{array}$ & Option 1 & Option 2 \\
\hline 1. & $\begin{array}{l}\text { Double-circuit } \\
\text { overhead line } 35 \mathrm{kV} \text { on } \\
\text { reinforced concrete } \\
\text { supports with } \\
\text { uninsulated steel- } \\
\text { aluminum wire with a } \\
\text { cross section of } 100 \text { to } \\
200 \mathrm{~mm}^{2}\end{array}$ & 9058374,72 & 246387792 & 324289815 \\
\hline 2. & $\begin{array}{l}\text { Standardized tariff } \\
\text { rates for covering the } \\
\text { costs of technological } \\
\text { connection of power } \\
\text { receivers of electricity } \\
\text { consumers, power grid } \\
\text { facilities belonging to } \\
\text { grid organizations and } \\
\text { other persons not } \\
\text { related to the } \\
\text { construction of power } \\
\text { grid facilities }\end{array}$ & 11113 & 11113 & 11113 \\
\hline 3. & $\begin{array}{l}\text { Preparation and } \\
\text { issuance of technical } \\
\text { specifications by the } \\
\text { network organization } \\
\text { to the Applicant }\end{array}$ & 3856 & 3856 & 3856 \\
\hline 4. & $\begin{array}{l}\text { Verification by the } \\
\text { network organization } \\
\text { of compliance with the } \\
\text { technical specifications }\end{array}$ & 7257 & 7257 & 7257 \\
\hline 5. & $\begin{array}{l}\text { Steel-aluminum wire } \\
\text { AS-120/19 }\end{array}$ & 107450 & 2922640 & 3846710 \\
\hline 6. & $\begin{array}{l}\text { SF6 circuit breaker and } \\
\text { disconnector }\end{array}$ & 1770000 & 1770000 & 3540000 \\
\hline 7. & $\begin{array}{l}\text { ABP IP54 Schneider } \\
\text { Electric }\end{array}$ & 82500 & 82500 & 0 \\
\hline \multicolumn{3}{|c|}{ Total: } & 251185158 & 331698751 \\
\hline
\end{tabular}

At the same time, the payback period for the construction of an overhead line according to the first possible option for improving the power supply system of LLC "Mine "Pervomayskaya" is 1.59 years, according to the second option is 2.10 years. Thus, the second option shows the greatest economic efficiency. 


\section{Conclusion}

The developed algorithm makes it possible to objectively assess the reliability of external power supply to coal mines, and in case of an unsatisfactory state of the electrical network, take measures to improve reliability. Reliability calculation by the information method of LLC "Mine "Pervomayskaya" showed high values of structural indicators, caused by powerful power sources and the absence of overloading of individual elements of the power supply system. From this we can conclude that this power supply system is reliable and stable. At the same time, it has a high potential for further development.

A modern coal enterprise needs to specialize in the full-scale implementation of the best available technologies and equipment. One of the priority areas of its activities should be to improve the reliability of power supply, reduce accidents and increase the level of industrial safety, and increase the energy efficiency of production. The innovative nature of the implemented information method for calculating reliability acts as an alternative to existing approaches to optimizing power supply systems that require large investments. The method makes it possible to take into account the transfer of information, since delays in the movement of operational information in the tracks formed during the elimination of accidents can significantly increase the downtime of technological equipment. This is another positive effect when choosing the best option. At the same time, the results of the research can be integrated into the concept of the development of. Smart Grids [15].

The introduction of the best available technologies and the modernization of fixed assets will help to increase the level of reliability of power supply to coal enterprises of Kuzbass and to protect the environment from the consequences of coal mining. It will also enable the implementation of efficient and safe development of coal deposits.

\section{References}

1. L. Jianfang, S. Xiaohui, W. Yuting, ICSAI, 1(3), 64 (2016)

2. D. Maheswaran, K. Jembu Kailas, W. Adithya Kumar, ICED, 23, 052004 (2015)

3. R. Honrubia-Escribano , E. Gymez-Lбzaro, A. Molina-Garcia, S. Marthn-Marthnez, Electrical Power and Energy Systems, 63, 846 (2014)

4. V. Efremenko, R. Belyaevsky, E. Skrebneva. E3S Web of Conferences 21, 02002 (2017)

5. P. Bujok, M. Klempa, V. Slivka, J. Ryba, I. Němec, V. Štastna, M. Porzer, Przeglad Geologiczny, 66 (6), 379 (2018)

6. A. Honrubia-Escribano, E. Gymez-Lzaro, A. Molina-Garcна, J.A. Fuentes, Electrical Power and Energy Systems, 41, 87 (2012)

7. A. Goswami, C. Gupta, G. Singh, International Journal of Electrical Power Energy Systems, 31(7-8), 418 (2009)

8. S. Gheorghe, C. Tanasa, S. Ene, M. Mihaescu, ICED, 18, (2005)

9. P. Mandatova, M. Massimiano, D. Verreth, C. Gonzalez, CIRED, 687, 066009 (2014).

10. C. Suhas, L. Nitin, R. Pillai, ICED, 23, (2015)

11. M. Ramos, M. Giacco, C. Tahan, C. Vieira, American Journal of Applied Sciences, 6 (4), 638 (2009)

12. P. Santarius, P. Krejci, Z. Brunclik, K. Prochazka, F. Kysnar, ICED, 23, (2015)

13. B. Hou, S.X. Xie, M. Chen, Y. Jin, D. Hao, R.S. Wang, Sci. Tech. 31(5), 458 (2013)

14. F. Nepsha, V. Voronin, R. Belyaevsky, V. Efremenko. E3S Web of Conferences 174, 03026 (2020)

15. R. Belyaevsky, A. Gerasimenko. E3S Web of Conferences 209, 02004 (2020) 